\title{
STUDIES ON THE EFFECT OF NATURAL FEEDS IN DIFFERENT COMBINATIONS ON GROWTH AND SURVIVAL OF CLARIAS GARIEPIN'US LARVAE
}

\author{
Gamal M. Abd El-Nasser \\ Central Lab for Aquaculture Research Abbassa, Sharkia, Egy'pt
}

Key words: Clarias gariepinus, larvae, feeding, primary nursing.

\section{ABSTRACT}

The suitability and potential of three live food were evaluated for I feeding Clarias gariepinus fry. Three-day old African catfish larvae (5-7 mm total length, $1.2-3.0 \mathrm{mg}$ body weight) were stocked at a density of 100 larvae per liter in nine glass aquaria $150 \times 50 \times 50$ $\mathrm{cm}$ each, representing three treatments. Each treatment was represented in three replicates). Fish were reared for 35 days on three different feeding regimes using Artemia salina, Moina macrocopa and Brachionus plicatilis as live food. Larvae of all treatments were fed on Brachionus at a density of 10 per $\mathrm{ml}$ in the first four days. From day 5, the three treatments were fed on Brachionus at a density of 20 per ml until day 9, for treatments 1 and 3, and day 15 for treatment 2 . In all rearing aquaria, Chlorella was added at a density of $1-3 \times 10^{5}$ cells per ml to serve as food for the rotifer and maintain good quality of water. Starting at day 10, Artemia nauplii were given to larvae of the first and third treatments initially at a density of 2 per $\mathrm{ml}$ in addition to Brachionus. The amount of Brachionus in the two treatments was gradually reduced to 10 per $\mathrm{ml}$ until it was completely removed on day 17. From this day to the end of the experimental trial, fish of the first treatment were fed on Artemia only, whose density was finally increased gradually to be 10 per ml. In treatment 3 , Moina macrocopa were fed to the Clarias gariepinus larvae in combination with Artemia from day 18 to day 20 and later on, Moina was fed until day 35. In treatment 2, fish continued to feed on Brachionus and feeding of fish on Artemia was delayed until day 15. Artemia nauplii were fed in combination with Brachionus until day 20 , after which only Artemia was given. Delaying feeding of Artemia nauplii until day 15 (in treatment 2) on resulted in slower larvae growth rates compared with fish fed Artemia starting on day 10. Partial replacement of Artemia nauplii by Moina macrocopa starting on day 17 showed a marked growth in larval growth over the delayed 
Ariemia treatment. There was no significant difference in the survival percentage of all treatments.

\section{INTRODUCTION}

In successful fish farm practices, consideration is generally given to the dietary protein component to produce optimal fish growth (Erfanullah, 1998). Equally important is the production of sufficient seed supply. The insufficient supply of the African catfish Clarias gariepinus limits its use in fish culture (De Kimp and Micha, 1974). The scarcity of Clarias fry or fingerlings in natural waters represents an obstacle in this regard. Controlled rearing of the fry indoor could be a reliable way to produce considerable numbers, however with small final average weights (Hogendoorn, 1980 and Abd El-Nasser, 1997). Consequently, the primary nursing phase indoors is necessary for rearing Clarias larvae. However alternatives should be paid into account to improve survival and growth performance of Clarias gariepinus larvae indoor. It has been realized that the application of live zooplankton as a source of supplementary food in nursery tanks especially under intensive culture is beneficial (Jana and Pal, 1987). Artemia salina nauplii are well suited as a starter feed for many fish species, when rearing of the fry is carried out indoors (Coche and Bianchi, 1997). This feed was also found valuable for rearing Clarias lazera fry in indoor tanks (Hogendoorn, 1980). Msiska, (1981) conducted an experiment on rearing the fry of African catfish Clarias lazera using live and artificial feed stuff. He found that feeding with live natural organisms during the first period was essential, both Artemia and zooplankton giving acceptable results and zooplankton was found to be equally suitable, which may be important in rearing Clarias fry when Artemia is difficult to obtain. Watanabe et al. (1983) stated that Moina is richer in nutrients compared to Artemia.

Hogendoorn (1983) carried out experimental investigations on feeding and early rearing of Clarias larvae to produce fingerlings indoors. Machiels and Henken (1985) examined the effect of the dietary protein levels on growth and food utilization of $(C$. gariepinus) using casein as the protein source. Degani et al. (1988) examined the effect of different protein levels and temperatures on food utilization, growth and body composition of $C$. gariepinus. 
The objective of this study was to evaluate the zooplankton supply in the primary nursing phase indoor and its effects on the growth performance of cultivated fish species. Also it aimed to determine the influence of delaying feeding of Artemia and partial replacement of Artemia by Moina on the growth and survival of Clarias gariepinus larvae.

\section{MATERIALS AND METHODS}

A number of the fully ripe females were brought from the production ponds at the Central Lab for Aquaculture Research, Abbassa, Egypt. They were kept in an earthen pond for 5 months. Feeding was administered 6 days a week, using $25 \%$ protein diet at a rate of $3 \%$ from the total biomass. In the spawning season when they reached ripe stage, females were injected with carp pituitary suspension $(4 \mathrm{mg} / \mathrm{kg}$ ). They were stripped by gentle pressure on the abdomen. The stripped eggs were collected in clean plastic pan. Eggs were fertilized and incubated according to the method described by Abd El-Nasser and El Ghobashy (2000). Newly hatched larvae (5-7 $\mathrm{mm}$ total length, 1.2-3.0 $\mathrm{mg}$ body weight) were stocked at a density of 100 larvae per liter in nine glass aquaria $150 \times 50 \times 50 \mathrm{~cm}$ each. Within 3 days of hatching after the yolk sac absorption period, the socalled fry started to search for food. The nine glass aquaria were randomiy divided into three groups representing three treatments (three replicates each). Fish were reared for 35 days on three different feeding regimes using Artemia salina, Moina macrocopa and Brachionus plicatilis as live food. Larvae of all treatment were fed on Brachionus at a density of 10 per $\mathrm{ml}$ in the first four days. From day 5 the three treatments were fed on Brachionus at a density of 20 per ml until day 9 , for treatments 1 and 3 , and day 15 for treatment 2 . In all rearing aquaria, Chlorella was added at a density of $1-3 \times 10^{5}$ cells per $\mathrm{ml}$ to serve as food for the rotifer and to maintain good water quality. Starting at day 10 , Artemia nauplii were given to larvae of the furst and third treatments initially at a density of 2 per $\mathrm{ml}$ in addition to Brachionus. The amount of Brachionus in the two treatments was gradually reduced to 1.0 per $\mathrm{ml}$ until it was completely removed on day 17. From this day to the end of the experimental trial, fish of the first treatment were fed on Artemia only, whose density was finally increased gradually to be 10 per $\mathrm{ml}$. In treatment 3 , Moina macrocopa 
were fed to the Clarias gariepinus larvae in combination with Artemia from day 18 to day 20 and later on Moina was fed until day 35. In treatment 2, fish continued to feed on Brachionus and feeding of fish on Artemia was delayed until day 15. Artemia nauplii were fed in combination with Brachionus until day 20 , after which only Artemia was given.

Rearing aquaria were cleaned by siphoning uneaten food and feces every morning prior to the first feeding. Water was changed daily using a rubber drain hose $(2.5 \mathrm{~cm}$ inside diameter) fitted with a plankton net-covered plastic bottle. About $15-50 \%$ of the total water volume was changed with fresh water from day 4 to day 15 . From day 16 until the end of rearing period, $50-75 \%$ of the water was changed. Throughout the rearing period, the water temperature ranged from 18 to $22{ }^{\circ} \mathrm{C}$. dissolved oxygen varied from $5-6.2 \mathrm{ppm}$ while $\mathrm{pH}$ ranged from 7.2 to 8.65 .

\section{RESULTS AND DISCUSSION}

The best growth in terms of mean total length (19.20 \pm 1.08 $\mathrm{mm})$ and body weight $(0.49 \pm 0.12 \mathrm{~g})$ was attained by Clarias gariepinus larvae fed Brachionus plus Artemia (treatment 1) as demonstrated in fig. 1. Fish in treatment 1 (Brachionus plus Artemia) and 3 (Miona) had similar growth rates. However, the survival rate ranged from $45.6 \%$ (treatment 3 ) to $65.9 \%$ (treatment 2) and did not vary significantly among the fish groups. Survival of fish fed Moina (treatment 3 ) was largely affected by cannibalism by "jumpers" (mean total length $39.0 \mathrm{~mm}$ ). However, growth of fish in this treatment was fast during the last five days of rearing (day 31-35). This confirmed the report of Femin (1991), however on a marine fish species, that 15-day old sea bass fed Moina had faster growth rates compared to larvae fed Artemia. Moina proved to be an excellent alternative live food to Artemia. It is considered a better source of highly unsaturated fatty acids (Watanabe et al., 1983).

\section{ACKNOWLEDGEMENT}

This is a collaborative research work between the Central Lab for Aquaculture Research, Abbassa and the Regional Council for Research and Extension. 


\section{REFERENCES}

Abd El-Nasser, G. (1997). Artificial propagation and early rearing of the African catfish Clarias gariepinus in Egyptian fishponds. Ph. D. Dissertation, Zoology Dept., Faculty of Science, Zagazig Univ., Benha branch, Egypt.

Abd El-Nasser, G. and Elghobashy, H. (2000). An assessment of the reproductive performance of wild and captive Clarias garicpinus. Annals of Agric. Sc., Moshtohor, Vol. 38 (1): 93-100.

Coche, A. G. and Bianchi, G.(1979). Present status of mass rearing of fry and fingerling in the EIFAC region. E. A. Huisman (eds); EIFAC Workshop on mass rearing of fry and fingerlings of freshwater fishes/papers. EIFAC/T 36 Suppl. 1. In:Msiska, O. V.(1981): Rearing of the fry of the African catfish, Clarias lazera (C \& V) using live and artificial feed staffs. Bamidgeh., 33(4):122-127.

Degani, G, Y. Ben-Zvi and D. Lvanon (1988). The effect of different dietary plotein sources and temperatures on growth and feed utilization of African catfish Clarias gariepinus (Burchell). Israeli Aquacult. Bamidgeh., 40 (4):113 -117.

De Kimp, P.and J. C. Micha (1974). First guidelines for the culture of Clarias lazera in Central Africa. Aquacuit., 4: 227 - 248.

Erfanullah, A. K. Jafra (1988). Effect of dietary carbohydrate-to lipid ratio on growth and body composition of walking catfish (Clarias batrachus). Aquacult., 161: 159-168.

Femin, A.C.(1991).Fresh water cladoceran Moina macrocopa (Strauss) as an alternative live food for rearing sea bass Altus calcarifer (Block) fry. Appl. Ichthyol., 7:8-14.

Hogendoom, H. (1980). controlled propagation of the African catfish, Clarias lazera (C.\& V.).III.Feeding and growth of fry. Aquacult., 21:232-241. 
Hogendoom, H. (1983). Growth and production of the African catfish, Clarias lazera (C. \& V.). III. Biogenetic relations of body weight and feeding level. Aquacult, 00 (1983).

Jana, B. B. and Pal, G. P. (1987). Effects of direct supply of liveplankton on the growth performance of carp fingerlings. Bamidgeh., 39 (3):76-83.

Machiels, M. A. M. and A. M. Henken (1985). Growth rate, feed utilization and energy metabolism of the African catfish Clarias gariepinus (Burchell), as affected by dietary protein and energy content. Aquacult, 44: $271-248$.

Msiska, O. V.(1981). Rearing of the fry of the African catfish, Clarias lazera $(\mathrm{C} \& \mathrm{~V})$ using live and artificial feedstaffs. Bamidgeh., 33 (4) : 122-127.

Watanabe, T.; Kitajima, C. and Fejita, J. (983). Nutritional values of live organisms used in Japan for mass propagation of fish. Aquacult., 34(22):115-143. 
Table 1: Schedule of feeding of Brachionus plicatilis (B), Artemia salina (A) and Moina macrocopa (M)to Clarias gariepinus larvae.

\begin{tabular}{|c|c|c|c|c|c|c|c|c|c|c|c|c|c|c|c|c|c|}
\hline \multirow{2}{*}{ Treat. } & \multicolumn{17}{|c|}{ Rearing period (day) } \\
\hline & 1 & & & & 9 & 10 & & 14 & & 1 & 18 & & 2 & & & 30 & \\
\hline 1 & B & B & B & B & B & $\mathrm{BA}$ & BA & $\mathrm{BA}$ & BA & BA & A & A & A & A & A & A & A \\
\hline 2 & B & B & B & B & B & B & B & B & BA & BA & $\mathrm{BA}$ & $\mathrm{BA}$ & $\mathrm{BA}$ & BA & A & A & A \\
\hline 3 & B & B & B & B & B & BA & BA & BA & BA & $\mathrm{BA}$ & A & AM & $\mathrm{AM}$ & AM & $M$ & M & M \\
\hline
\end{tabular}

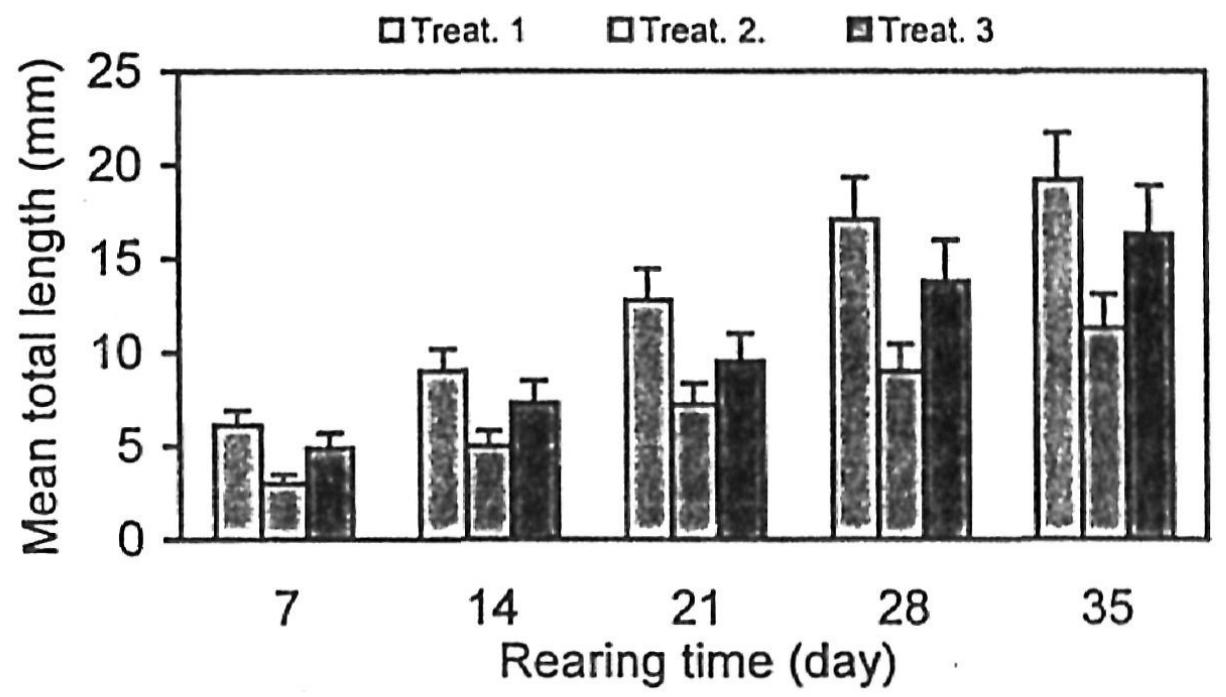

Fig. 1. Mean total length (mm) of African catfish, Clarias gariepinus, larvae fed on different regimes using live zooplankton food. Treatment $1=$ Brachionus plicatilis and Artemia salina; treatment $2=$ Brachionus plus delayed introduction of Artemia; treatment $3=$ Brachionus, Artemia and Moina macrocopa.Vertical lines above each barrepresent standard deviation (SD). 


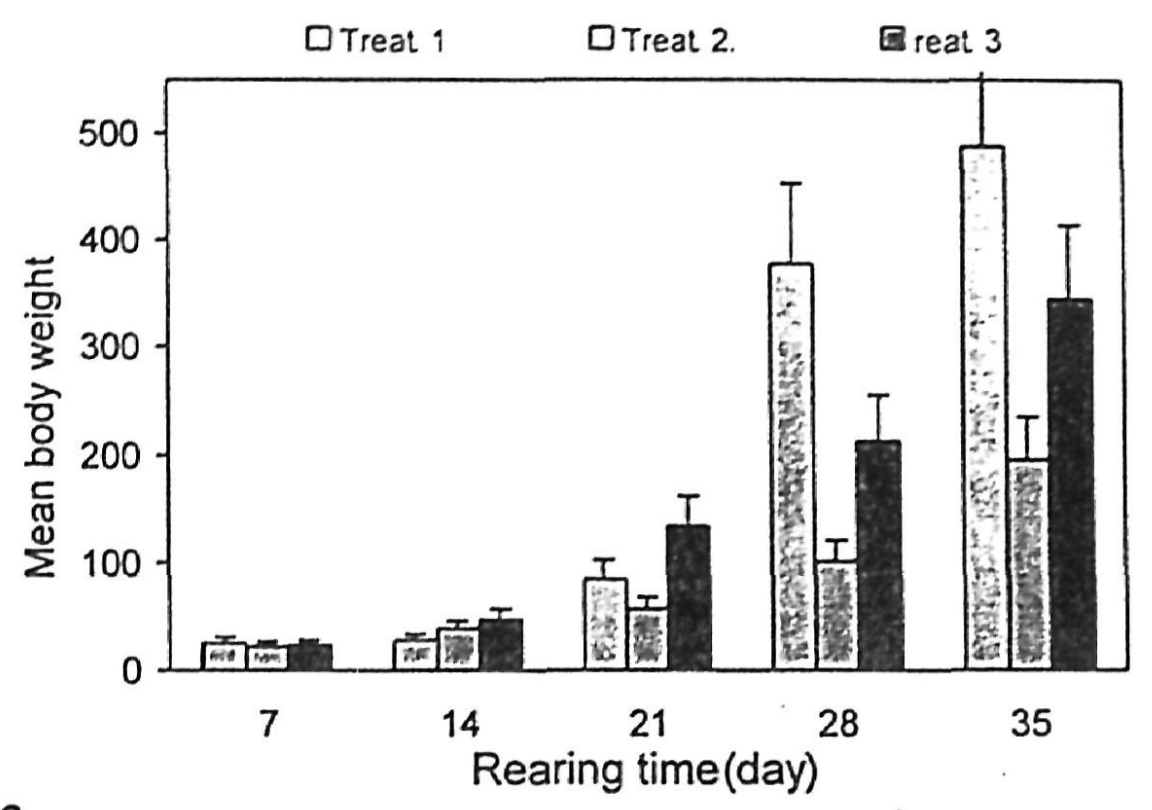

Fig. 2.

Mean body weight (mg) of African catfish, Clarias gariepinus, larvae fed on different regimes using live zooplankton food.Treatment $1=$ Brachionus plicatilis and Artemia salina; treatment $2=$ Brachionus plus delayed introduction of Artemia; treatment $3=$ Brachionus, Artemia and Moina macrocopa. Vertical lines above each bar represent standard deviation (SD).

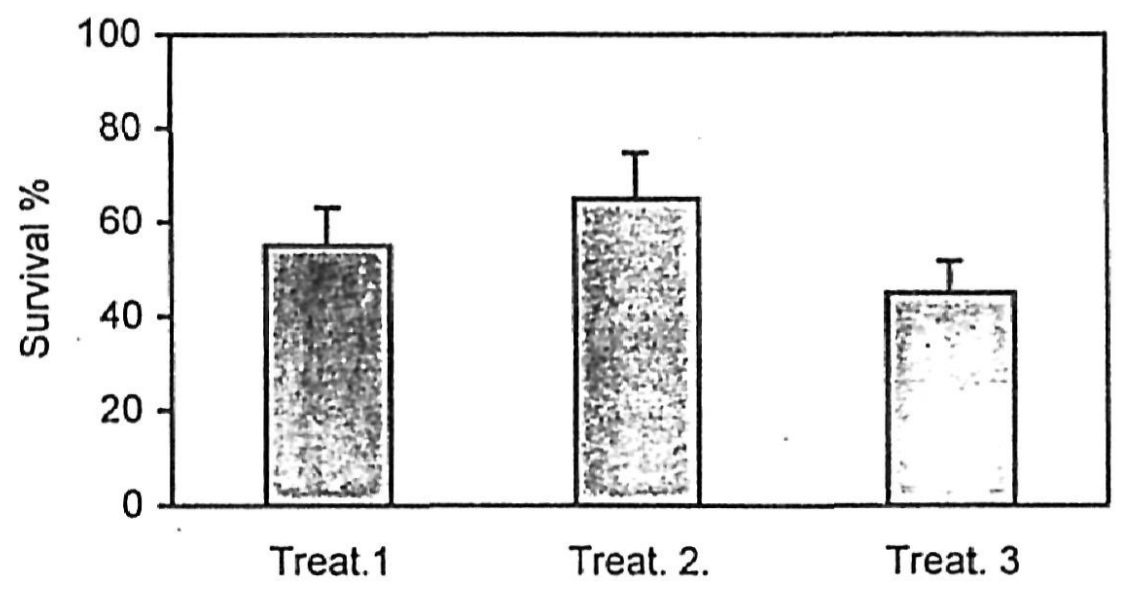

Fig. 3.

Survival percentage of African catfish, Clarias gariepinus, larvae fed on different regimes using live zooplankton food. Treatment $=$ Brachionus plicatilis and Artemia salina; treatment $2=$ Brachionus plus delayed introduction of Artemia; treatment $3=$ Brachionus, Artemia and Moina macrocopa. Vertical lines above each bar represent standard deviation (SD). 